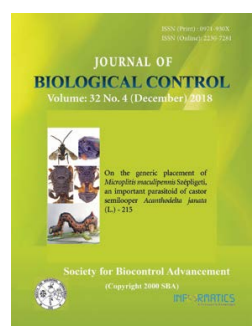

Research Article

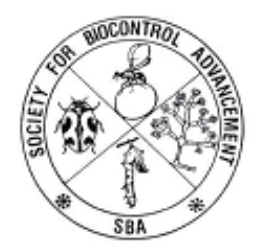

\title{
Molecular characterization of an indigenous lepidopteran toxic Bacillus thuringiensis strain T532
}

\author{
K. V. NAYAN GANESH, A. L. REYAZ and N. BALAKRISHNAN* \\ Department of Plant Biotechnology, Centre for Plant Molecular Biology and Biotechnology, \\ Tamil Nadu Agricultural University, Coimbatore - 635110, Tamil Nadu, India \\ *Corresponding authorE-mail: bala8775@gmail.com
}

\begin{abstract}
Bacillus thuringiensis Berliner (Bt) being an eco-friendly bioinsecticide is effectively used in pest management strategies and, therefore, isolation and identification of new strains effective against a broad range of target pests is important. In the present study, four indigenous $B t$ isolates (T489, T491, T495 and T532) were taken and investigated for their properties such as crystal morphology, cry gene(s) content and insecticidal activity. Bipyramidal, cuboidal and spherical crystals were observed. Among the four isolates only one isolate was found positive for lepidopteran specific $c r y$ genes. The isolate T532 which showed the presence of $c r y 1$, $c r y 2 A a$ and $c r y 2 A b$ genes was selected for protein profiling and bioassay. The isolate showed the presence of two proteins of molecular weights at $\sim 135$ and $\sim 65 \mathrm{kDa}$ sizes. Artificial diet based bioassay resulted in 100\% mortality of the neonate larvae of H. armigera and S. litura for the isolate T532 which was comparable to that of the positive control (HD1). The full length cry $2 A$ gene was amplified and cloned into E. coli DH5 $\alpha$ strain. The recombinant plasmids were sequenced and the sequence was deposited in GenBank nucleotide database. The accession number of the gene is MH475905. The gene was named by the Bacillus thuringiensis delta endotoxin nomenclature committee as cry2Aa23.
\end{abstract}

KEY WORDS: Bacillus thuringiensis, Cloning, cry2Aa, PCR

(Article chronicle: Received: 16-05-2018; Revised: 10-11-2018; Accepted: 15-12-2018)

\section{INTRODUCTION}

Bacillus thuringiensis Berliner (Bt) is a Gram positive, sporulating bacterium, which is a common inhabitant of soil and aquatic ecosystems (Bernhard et al., 1997; Konecka et al., 2012). The importance of Bt in the field of agriculture is in the form of a potential bioinsecticide which holds toxicity against a broad range of insects belonging to the orders Coleoptera, Lepidoptera, Diptera, Mallophaga, Hymenoptera and Homoptera (Schnepf et al., 1998; Palma et al., 2014). This property of $\mathrm{Bt}$ is conferred by the molecules which they produce such as crystal (Cry) proteins and vegetative insecticidal proteins (Vip) which are formed during sporulation and vegetative phases respectively (Ali et al., 2010). The crystalline protein which is in a protoxin form is solubilized inside the midgut of the insect by the gut protease enzymes and the toxin is released (Milne and Kaplan, 1993). This toxin binds to the brush border membrane of the midgut epithelial tissue and creates pores which ultimately lead to the lysis of epithelial cells followed by the death of the larvae (Ali et al., 2010).
Various chemical pesticides such as organic phosphates and synthetic pyrethroids are applied in the field at the rate of $8 \times 10^{24}$ and $3 \times 10^{22}$ molecules/hectare respectively whereas the need of commercial $\mathrm{Bt}$ insecticides is only $10^{20}$ molecules/hectare (Feitelson et al., 1992). This shows the increased potential of Bt bioinsecticide over the commonly used chemical pesticides. As of $10^{\text {th }}$ July 2018, a total of $319 \mathrm{Bt}$ holotype toxins (Crickmore et al., 2016; http://www. btnomenclature.info/) have been reported since 1981, in which the first ever report of cloning a cry gene was made by Schnepf and Whiteley. The characterization of Bt isolates and identification of potential toxins lead to identification of novel potential gene(s) and which in turn will be helpful for the development of transgenic crop plants with insect resistance. The reports of insects developing resistance against existing $\mathrm{Bt}$ toxins improved the scope of research on novel isolates with broad spectrum of insecticidal activity. Cloning and expression of the toxins in other microorganisms helped in identifying the individual effects of the toxins towards the target insects (Jain et al., 2006; Yilmaz et al., 2017). 
The present study was conducted in order to characterize four $\mathrm{Bt}$ isolates taken from the collection being maintained in Bt lab, Dept. of Plant Biotechnology, Centre for Plant Molecular Biology and Biotechnology (CPMB\&B), Tamil Nadu Agricultural University (TNAU), Coimbatore.

\section{MATERIALS AND METHODS}

\section{Bacterial strains and plasmids}

Four indigenous isolates of Bacilllus thuringiensis were chosen from the collection maintained in Bt lab, Department of Plant Biotechnology, CPMB\&B, TNAU, Coimbatore. The isolates taken for characterization were T489, T491, T495 and T532. The isolates were revived from glycerol stocks and cultured in $\mathrm{T}_{3}$ medium. The Bt isolates $\mathrm{HD} 1$ and $4 \mathrm{G} 1$, obtained from Bacillus Genetic Stock Center (Ohio State University, USA) were used as positive controls and the strain 4Q7 was used as negative control for the experiments. T/A cloning vector $\mathrm{pTZ57R/T}$ were used for cloning of the insert into Escherechia coli DH5 $\alpha$ strain.

\section{PCR analysis for lepidopteran toxic genes}

According to the protocol given by Kalman et al., (1993), total genomic DNA was isolated from the isolates and used for performing PCR screening. Universal primers (Ben-Dov et al., 1997 and 1999) for various lepidopteran toxic genes such as $c r y 1, c r y 2 A a, c r y 2 A b$ and $c r y 9$ (Table 1 ) were used for identifying the presence of respective genes in the isolates. For $25 \mu \mathrm{l}$ of polymerase chain reaction, $0.1 \mu \mathrm{g}$ of total genomic DNA and 50ng of each primer were mixed with $2.5 \mu \mathrm{l}$ of $10 \mathrm{X}$ buffer, $2.5 \mu \mathrm{l}$ of $2.5 \mathrm{mM}$ dNTPs, $0.5 \mu \mathrm{l}$ DNA polymerase of $3 \mathrm{U} / \mu \mathrm{l}$ (GeNeiTM, Bengaluru, India). Bt reference strain HD1 was used as positive control for cryl, cry $2 A a$ and $c r y 2 A b$ genes and $4 \mathrm{G} 1$ was used as the positive control for cry9.

\section{Harvesting spore-crystal mixture from the isolates}

The bacterial mother culture was initiated in $5 \mathrm{ml}_{\text {of }} \mathrm{T}_{3}$ broth and incubated in a rotary shaker (Scigenics Orbitek, India) set at $180 \mathrm{rpm}$ at $30^{\circ} \mathrm{C}$. From the overnight grown culture, $50 \mu \mathrm{l}$ was inoculated in $25 \mathrm{ml} \mathrm{T}_{3}$ broth and incubated at $30^{\circ} \mathrm{C}$ with shaking. After a period of 48 hours, the sporulation of the bacterial culture was monitored through phase contrast microscope. When it appeared that more than 90 per cent of the cells got lysed, the culture was transferred to $4^{\circ} \mathrm{C}$ for a minimum of half an hour. The culture was then centrifuged at $10,000 \mathrm{rpm}$ for 10 minutes at $4^{\circ} \mathrm{C}$. The pellet obtained was washed with $5 \mathrm{ml}$ of ice-cold Tris-EDTA buffer [Tris $10 \mathrm{mM}$, EDTA $1 \mathrm{mM}, \mathrm{pH} 8.0$ with $1 \mathrm{mM}$ phenyl methyl sulphonyl fluoride (PMSF)]. After centrifugation, the pellet was washed with $5 \mathrm{ml}$ of ice-cold $0.5 \mathrm{M}$ sodium chloride which was followed by two more washes with $5 \mathrm{ml}$ of Tris-EDTA buffer with $0.5 \mathrm{mM}$ PMSF by centrifuging at the same speed and time. Finally, the spore-crystal pellet was suspended in $100 \mu \mathrm{l}$ of sterile distilled water containing $1 \mathrm{mM}$ PMSF and stored at $-20^{\circ} \mathrm{C}$.

Preliminary toxicity of the isolate T532 against Helicoverpa armigera and Spodoptera litura

Laboratory reared neonate larvae of $H$. armigera and $S$. litura were used for surface contaminated artificial diet based insect bioassay for the isolates. Artificial diet (Nagarkatti and prakash, 1974) was poured into cryovials and the sporecrystal mixture of the isolate was coated on the surface evenly. For each isolate, three replications were maintained and for each replication, 10 larvae were used in individual

Table 1: Oligonucleotide primers used for PCR screening of the Bacillus thuringiensis isolates

\begin{tabular}{|c|c|c|c|c|}
\hline S. No. & $\begin{array}{l}\text { Primer Sequences } \\
\quad 5 \text { ' to } 3 \text { ' }\end{array}$ & cry genes & Amplicon size (bp) & Reference \\
\hline 1. & $\begin{array}{l}\text { FP: CATGATTCATGCGGCAGATAAAC } \\
\text { RP: TTGTGACACTTCTGCTTCCCATT }\end{array}$ & cryl & 277 & \multirow{3}{*}{$\begin{array}{l}\text { Ben-dov et al. } \\
\quad(1997)\end{array}$} \\
\hline 2. & $\begin{array}{l}\text { FP: GTTATTCTTAATGCAGATGAATGGG } \\
\text { RP: GAGATTAGTCGCCCCTATGAG }\end{array}$ & cry $2 A a$ & 498 & \\
\hline 3. & $\begin{array}{l}\text { FP: GTTATTCTTAATGCAGATGAATGGG } \\
\text { RP:TGGCGTTAACAATGGGGGGAGAAAT }\end{array}$ & cry $2 A b$ & 546 & \\
\hline 4. & $\begin{array}{l}\text { FP: CGGTGTTACTATTAGCGAGGGCGG } \\
\text { RP: GTTTGAGCCGCTTCACAGCAATCC }\end{array}$ & crys & 354 & $\begin{array}{l}\text { Ben-dov et al. } \\
\quad \text { (1999) }\end{array}$ \\
\hline
\end{tabular}


vials. Artificial diet surface coated with spore crystal mixtures of HD1 and 4Q7 was used as positive and negative controls respectively. Besides, empty diet was also used a negative control. Observations were taken in every 24 hour intervals for one week.

\section{Protein profiling of the potential isolate}

The isolate showing potential toxicity against the neonate larvae of $H$. armigera and $S$. litura were selected and performed SDS-PAGE analysis to identify the protein profile of them. The experiment was carried out following the protocol provided by Laemmli (1970). Stacking gel of 4 per cent and separating gel of 9 per cent were used for SDS-PAGE. HD1 was used as positive control and 4Q7 as negative control. The molecular weight of proteins was determined using higher range protein molecular weight marker (myosin rabbit muscle $205 \mathrm{kDa}$, phosphorylase b $97.4 \mathrm{kDa}$, bovine serum albumin $65 \mathrm{kDa}$, ovalbumin $43 \mathrm{kDa}$ and carbonic anhydrase $29 \mathrm{kDa}$ ) obtained from GeNeiTM, Bangalore, India.

\section{Cloning of cry2A gene}

The full length $\operatorname{cry} 2 \mathrm{~A}$ gene was amplified from $\mathrm{Bt}$ isolate T532 using the forward primer 2AFS (ATGGTACC ATGAATAATGTATTGAATAGTGGAA) and reverse primer 2ARS (GTTCTAGACTCAAACCTTAATAAAGTGGTG). The PCR reaction was carried out in a total volume of 25 $\mu \mathrm{l}$ in a Thermal cycler (Eppendorf Mastercycler personal, Germany). The PCR product was purified using a PCR clean up kit (Thermo Scientific, USA) and was ligated into $\mathrm{pTZ57R/T}$ vector and cloned into $E$. coli $\mathrm{DH} 5 \alpha$ strain and the plasmid was isolated and sequenced at Eurofins Genomics India Pvt. Ltd. The sequence was deposited in GenBank and accession number was obtained. The sequence was submitted to $B$. thuringiensis delta endotoxin nomenclature committee.

\section{RESULTS AND DISCUSSION}

Bacillus thuringiensis is a ubiquitous bacterium found in various habitats such as soil, phylloplane, dead insects, dust, spider web etc. (Mizuki et al., 1999; Asokan and Puttaswamy, 2007; Ramalakshmi and Udayasuriyan, 2010; Unalmis et al., 2015 and Reyaz et al., 2017). In the present study, the isolates preserved in glycerol stocks were revived and cultured in $\mathrm{T}_{3}$ medium. The cultures were monitored for the presence of more than 90 per cent lysis and the crystal morphology was studied at this stage using phase contrast microscope. Among the isolates studied, the isolate T532 showed the presence of three types of crystal proteins such as bipyramidal, cuboidal and spherical (Fig. 1). Only bipyramidal crystals were observed in T491 and T495 whereas cuboidal crystals were observed in T489. Jain et al. (2017) and Reyaz et al. (2017) reported the presence of various kinds of crystals such as spherical, bipyramidal, cuboidal and irregular shapes. Earlier the predominance of bipyramidal crystals was also reported by Bernhard et al. (1997), Martin and Travers (1989) and Ramalakshmi and Udayasuriyan (2010).

Crickmore et al. (1998) reported that lepidopteran specific toxins are produced by cry genes. The isolates were subjected to PCR screening for the presence of lepidopteran specific cry gene(s) using primers as described by Ben-Dov et al., 1997 and 1999. While screening by PCR with gene specific primers viz., cryl, cry $2 A a$ and $c r y 2 A b$, the Bt isolate T532 only showed the amplicon sizes of $\sim 277 \mathrm{bp}, \sim 500 \mathrm{bp}$ and $\sim 550$ bp respectively (Fig. 2). No amplification was obtained for $\operatorname{cry} 9$ gene. Patel and Ingle (2012) performed PCR screening for the selected isolates and found the presence of cry 1 and cry 2 genes in two and one isolates respectively. The abundance of cry genes in the Bt strains from Bangladesh was screened by Shishir et al. (2014) and reported cryl gene as the most abundant with (30.8\%) followed by cry $2(25.5 \%)$, cry3 (22.2\%) and cry9 (7.2\%) genes.

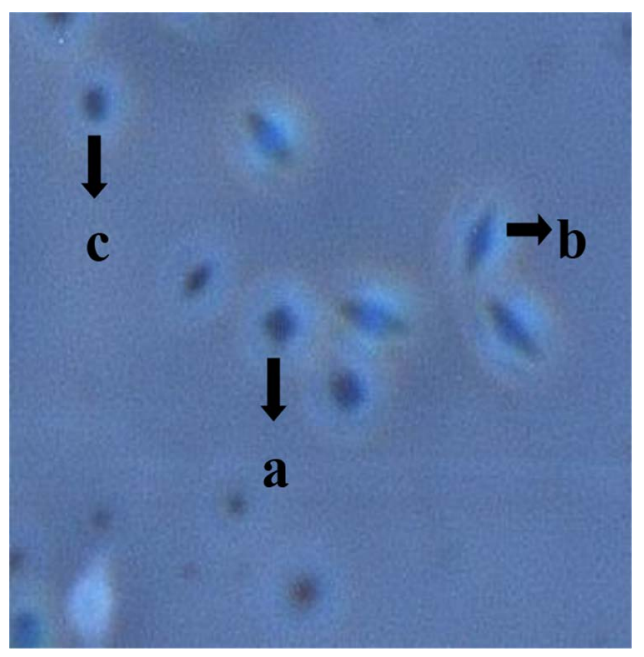

Fig. 1. Different types of crystals present in the $B t$ isolate T532 a. Cuboidal, b. Bipyramidal and c. Spherical.
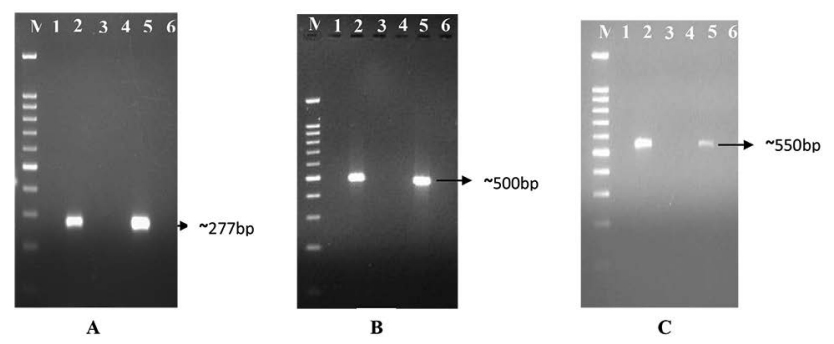

Fig. 2. A) PCR screening of cryl gene, B) PCR screening of cry2Aa gene and C) PCR screening of cry2 Ab gene.

Lane M: 100bp Ladder, Lane 1: Negative control, Lane 2: Positive control (HD1), Lane 3: T489, Lane 4: T491, Lane 5: T532 and Lane 6: T495. 
Preliminary bioassay with spore-crystal mixture of T532 $\mathrm{Bt}$ isolate showed 100 per cent mortality of the neonate larvae of both Helicoverpa armigera and Spodoptera litura using surface contaminated artificial diet based bioassay. This was comparable to the toxicity with the positive control Bt HD1 (Fig. 3). No mortality was observed in negative controls (i.e.,) diet coated with $4 \mathrm{Q} 7$ spore crystal mixture and empty diet. Reyaz et al. (2017) also followed surface contamination method for bioassay against $S$. litura larvae and found one among the 68 isolates with 100 per cent mortality. Unalmis et al. (2015) reported a reduced toxicity of the local Bt isolates against two stored grain pests, Ephestia kuehniella and Plodia interpunctella when compared to the reference strain.

SDS-PAGE analysis of spore-crystal mixture of T532 Bt isolate showed the presence of two distinct proteins of $\sim 135$ and $\sim 65 \mathrm{kDa}$ similar to that of the reference strain HD1 (Fig. 4). The reference strain 4Q7 was used as negative control which showed no proteins. The presence of a protein of $\sim 130$ to 135 $\mathrm{kDa}$ molecular weight indicates the presence of either cryl or cry 9 gene(s) and a protein of molecular weight $\sim 60$ to 70 are considered to be the result of cry2 gene (Jain et al., 2006; Zheng et al., 2010 and Reyaz and Arulselvi, 2016). Ramalakshmi and Udayasuriyan (2010) reported earlier that out of the $70 \mathrm{Bt}$ isolates analyzed, 17 isolates (24.2\%) representing cry $2 A$ gene exhibited two major polypeptide bands with molecular weights

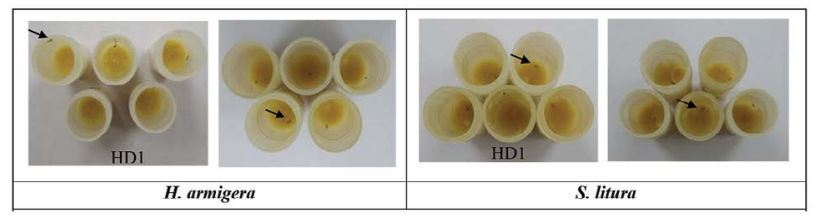

Fig. 3. Artificial diet based bioassay of the Bt isolate T532.

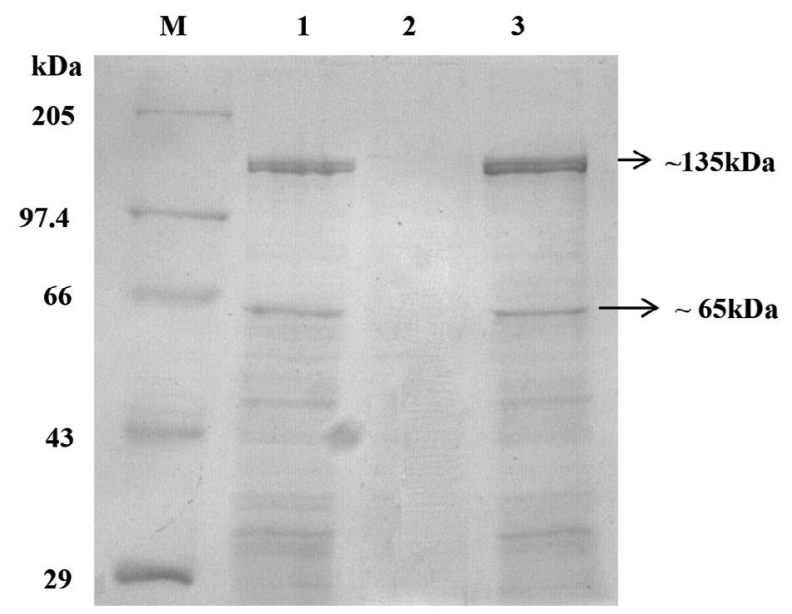

Fig. 4. SDS-PAGE protein profiling of spore-crystal mixture. Lane M: High MW Protein marker, Lane 1: HD1, Lane 2: 4Q7 and Lane 3: T532. in the range of $\sim 135$ and $\sim 65 \mathrm{kDa}$.

The full ORF of the gene cry $2 A$ was amplified using gene specific primers and an amplified product of $\sim 1.9 \mathrm{~kb}$ was obtained (Fig. 5). The purified PCR product was ligated into a T/A cloning vector $\mathrm{pTZ} 57 \mathrm{R} / \mathrm{T}$ and was transformed into E. coli $\mathrm{DH} 5 \alpha$ cells. The recombinant cells were identified by blue-white screening and confirmed by colony PCR. The recombinant plasmid was isolated from transformed colony and sequenced at Eurofins Genomics India Pvt. Ltd. using an automated DNA sequencer (ABI 3730xl Genetic). The sequence was aligned with an existing $c r y 2 \mathrm{Aa}$ gene sequence (M31738.1) which showed a similarity of 100 per cent among the sequences. The sequence was deposited in GenBank nucleotide database and the accession number is MH475905. The gene sequence and its deduced amino acid sequence were submitted to Bacillus thuringiensis delta endotoxin nomenclature committee and it was named as cry2Aa23. Manikandan et al. (2015) reported the cloning of $c r y 2 A$ gene from an indigenous $B t$ isolate using T/A cloning vector and the sequencing results revealed 99 per cent homology of the sequence with that of $c r y 2 \mathrm{Aal}$. Likewise cloning of crylAb (Darsi et al., 2010), cry2Ab (Jain et al., 2006 and Pan et al., 2014), cry2Ac (Sasaki et al., 1997) and cry9 (Ben-Dov et al., 1999; Wasano et al., 2005) genes were cloned and characterized.

Based on the PCR screening, preliminary insect bioassay

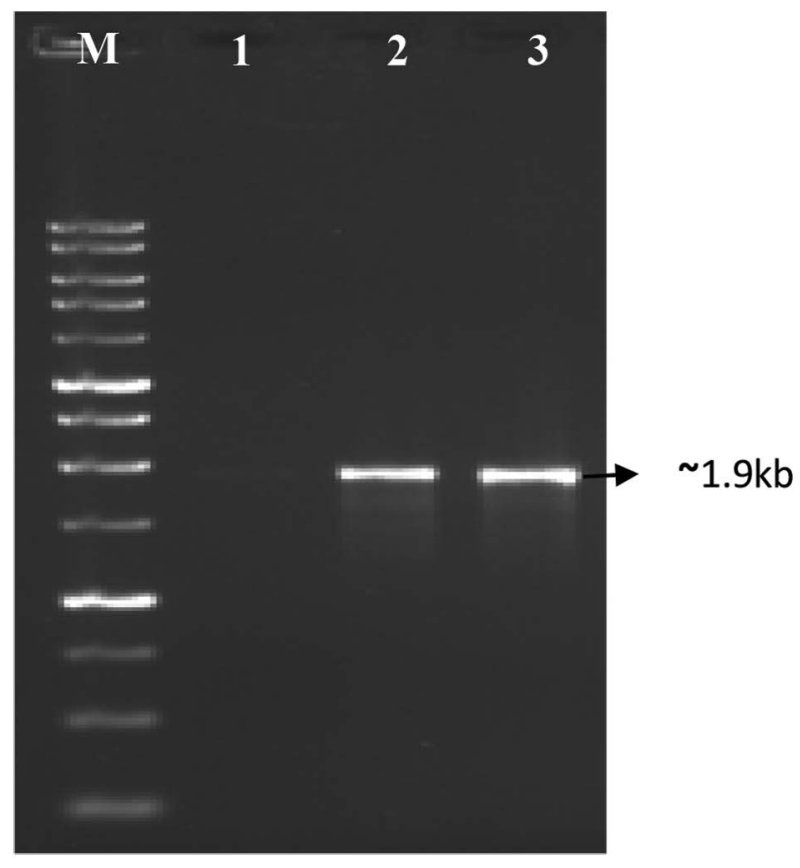

Fig. 5. Amplification of full length cry2A gene.

Lane M: 1kb Ladder, Lane 1: Negative control, Lane 2: Positive control (HD1) and Lane 3: T532. 
and protein profile, it is evident that T532 is a potential indigenous $\mathrm{Bt}$ isolate against lepidopteran insect pests $(H$. armigera and $S$. litura). Further work need to be done to evaluate its full potential.

\section{ACKNOWLEDGEMENT}

The authors are thankful to Tamil Nadu Agricultural University for providing all the facilities to carry out the study.

\section{REFERENCES}

Ali S, Zafar Y, Ali GM, Nazir F. 2010. Bacillus thuringiensis and its application in agriculture. Afr J Biotechnol. 9(14): 2022-2031.

Asokan R, Puttaswamy. 2007. Isolation and characterization of Bacillus thuringiensis Berliner from soil, leaf, seed dust and insect cadaver. J Biol Control. 21(1): 83-90.

Ben-Dov E, Wang Q, Zaritsky A, Manasherob R, Barak Z, Schneider B, Khamaraev A, Baizhanov M, Glupov V, Margalith Y. 1999. Multiplex PCR screening to detect cry9 genes in Bacillus thuringiensis strains. Appl Environ Microbiol. 65(8): 3714-3716. PMid:10427071 PMCid:PMC91556

Ben-Dov E, Zaritsky A, Dahan E, Barak ZE, Sinai R, Manasherob R, Khamraev A, Troitskaya E, Dubitsky A, Berezina N. (1997). Extended screening by PCR for seven cry-group genes from field-collected strains of Bacillus thuringiensis. Appl Environ Microbiol. 63(12): 4883-4890. PMid:9406409 PMCid:PMC168816

Bernhard K, Jarrett P, Meadows M, Butt J, Ellis DJ, Roberts GM, Pauli S, Rodgers P, Burges HD. 1997. Natural isolates of Bacillus thuringiensis worldwide distribution, characterization and activity against insect pests. $J$ Invertebr Pathol. 70: 59-68 https://doi.org/10.1006/ jipa.1997.4669

Crickmore N, Baum J, Bravo A, Lereclus D, Narva K, Sampson K, Schnepf E, Sun M, Zeigler DR. 2016. Bacillus thuringiensis toxin nomenclature. Available from: http://www.btnomenclature.info

Crickmore N, Zeigler DR, Feitelson J, Schnepf E, Van Rie J, Lereclus D, Baum J, Dean DH 1998. Revision of nomenclature for the Bacillus thuringiensis pesticidal crystal proteins. Microbiol Mol Biol Rev. 62: 807-813. PMid:9729610 PMCid:PMC98935
Darsi S, Prakash GD, Udayasuriyan V. 2010. Cloning and characterization of truncated $c r y 1 \mathrm{Ab}$ gene from a new indigenous isolate of Bacillus thuringiensis. Biotechnol Lett. 32(9): 1311-1315. https://doi.org/10.1007/s10529. 010-0301-1 PMid:20480206

Feitelson JS, Payne J, Kim L. 1992. Bacillus thuringiensis: insects and beyond. Nature Biotechnol. 10: 271-275. https://doi.org/10.1038/nbt0392-271

Jain D, Sunda SD, Sanadhya S, Nath DJ, Khandelwal SK. 2017. Molecular characterization and PCR-based screening of cry genes from Bacillus thuringiensis strains. 3 Biotech 7(1): 4. https://doi.org/10.1007/s13205-016-0583-7 PMid:28391468 PMCid:PMC5385171

Jain D, Udayasuriyan V, Arulselvi PI, Dev SS, Sangeetha P. 2006. Cloning, characterization, and expression of a new cry $2 \mathrm{Ab}$ gene from Bacillus thuringiensis strain 14-1. Appl Biochem Biotechnol. 128(3): 185-194. https://doi. org/10.1385/ABAB:128:3:185

Kalman S, Kiehne KL, Libs JL, Yamamoto T. 1993. Cloning of a novel cryIC-type gene from a strain of Bacillus thuringiensis subsp. galleriae. Appl Environ Microbiol. 59(4): 1131-1137. PMid:8476286 PMCid:PMC202250

Konecka E, Baranek J, Hrycak A, Kaznowski A. 2012. Insecticidal activity of Bacillus thuringiensis strains isolated from soil and water. Sci World J. Article ID: 710501. doi:10.1100/2012/710501. https://doi. org/10.1100/2012/710501

Kumar S, Singh A. 2015. Biopesticides: Present status and the future prospects. J Fertil Pestic. 6(2): 1-2. https:// doi.org/10.4172/2471-2728.1000e129

Laemmli UK. 1970. Cleavage of structural proteins during the assembly of the head of bacteriophage T4. Nature 227(5259): 680-685. https://doi.org/10.1038/227680a0 PMid:5432063

Manikandan R, Ramalakshmi A, Balasubramani V, Udayasuriyan V. 2015. Characterization and cloning of the cry2A gene from indigenous isolates of Bacillus thuringiensis. Mol. Bio. 49(4): 520-526. https://doi. org/10.1134/S0026893315040111

Martin PA, Travers RS. 1989. Worldwide abundance and distribution of Bacillus thuringiensis isolates. Appl Environ Microbiol. 55(10): 2437-2442. PMid:16348022 PMCid:PMC203101 
Milne R, Kaplan H. 1993. Purification and characterization of a trypsin-like digestive enzyme from spruce budworm (Choristoneura fumiferana) responsible for the activation of $\delta$ - endotoxin from Bacillus thuringiensis. Insect Biochem Molec Biol. 23: 663-673. https://doi. org/10.1016/0965-1748(93)90040-Y

Mizuki E, Ichimatsu T, Hwang SH, Park Y, Saitoh H, Higuchi K, Ohba M. 1999. Ubiquity of Bacillus thuringiensis on phylloplanes of arboreous and herbaceous plants in Japan. J Appl Microbiol. 86(6): 979-984. https://doi. org/10.1046/j.1365-2672.1999.00778.x

Nagarkatti S, Prakash S. 1974. Rearing of Heliothis armigera (Hub.) on artificial diet. Tech Bull Commonwealth Inst Biol Control 17: 169-173.

Palma L, Mu-oz D, Berry C, Murillo J, Caballero P. 2014. Bacillus thuringiensis toxins: an overview of their biocidal activity. Toxins 6(12): 3296-3325. https://doi.org/10.3390/ toxins6123296 PMid:25514092 PMCid:PMC4280536

Pan Z, Xu L, Zhu Y, Shi H, Chen Z, Chen M, Chen Q, Liu B. 2014. Characterization of a new cry $2 \mathrm{Ab}$ gene of Bacillus thuringiensis with high insecticidal activity against Plutella xylostella L. World J Microbiol Biotechnol. 30(10): 2655-2662. https://doi.org/10.1007/s11274014-1689-x PMid:24943249

Patel KD, Ingle SS. 2012. Molecular characterization of novel serovars of Bacillus thuringiensis isolates from India. Indian J Microbiol. 52(3): 332-336. https:// doi.org/10.1007/s12088-011-0240-0 PMid:23997321 PMCid:PMC3460129

Ramalakshmi A, Udayasuriyan V. 2010. Diversity of Bacillus thuringiensis isolated from Western Ghats of Tamil Nadu state, India. Curr Microbiol. 61(1): 13-18. https:// doi.org/10.1007/s00284-009-9569-6 PMid:20033169

Reyaz AL, Arulselvi PI. 2016. Cloning, characteriztion and expression of a novel haplotype cry2A-type gene from Bacillus thuringiensis strain SWK1, native to Himalayan valley Kashmir. J Invertebr Pathol. 136: 1-6. https://doi. org/10.1016/j.jip.2016.02.005 PMid:26906447

Reyaz AL, Gunapriya L, Arulselvi PI. 2017. Molecular characterization of indigenous Bacillus thuringiensis strains isolated from Kashmir valley. 3 Biotech 7(2): 143. https://
doi.org/10.1007/s13205-017-0756-Z

PMCid:PMC5465046

Sasaki J, Asano S, Hashimoto N, Lay BW, Hastowo S, Bando H, Iizuka T. 1997. Characterization of a cry2A gene cloned from an isolate of Bacillus thuringiensis serovar sotto. Curr Microbiol. 35(1): 1-8. https://doi. org/10.1007/s002849900201 PMid:9175551

Schnepf E, Crickmore N, Van Rie J, Lereclus D, Baum J, Feitelson J, Zeigler D, Dean D. 1998. Bacillus thuringiensis and its pesticidal crystal proteins. Microbiol Mol Biol Rev. 62(3): 775-806. PMid:9729609 PMCid:PMC98934

Schnepf HE, Whiteley H. 1981. Cloning and expression of the Bacillus thuringiensis crystal protein gene in Escherichia coli. Proc Natl Acad Sci. 78(5): 2893-2897. https://doi.org/10.1073/pnas.78.5.2893

Shishir A, Roy A, Islam N, Rahman A, Khan S, Hoq MM. 2014. Abundance and diversity of Bacillus thuringiensis in Bangladesh and their cry genes profile. Front Environ Sci. 2: 1-10. https://doi.org/10.3389/fenvs.2014.00020

Unalmis S, Ayvaz A, Yilmaz S, Azizoglu U. 2015. Molecular screening and bioactivity of native Bacillus thuringiensis isolates. J Agric Sci Technol. 17(5): 1197-1207.

Wasano N, Saitoh H, Maeda M, Ohgushi A, Mizuki E, Ohba M. 2005. Cloning and characterization of a novel gene cry9Ec1 encoding lepidopteran-specific parasporal inclusion protein from a Bacillus thuringiensis serovar galleriae strain. Can J Microbiol. 51(11): 988-995. https://doi.org/10.1139/w05-084 PMid:16333339

Yilmaz S, Azizoglu U, Ayvaz A, Temizgul R, Atciyurt ZB, Karaborklu S. 2017. Cloning and expression of cry2Aa from native Bacillus thuringiensis strain SY49-1 and its insecticidal activity against Culex pipiens (Diptera: Culicidae). Microb Pathogenesis 105: 81-85. https://doi. org/10.1016/j.micpath.2017.02.016 PMid:28215855

Zheng A, Zhu J, Tan F, Guan P, Yu X, Wang S, Deng Q, Li S, Liu H, Li P. 2010. Characterisation and expression of a novel haplotype cry2A-type gene from Bacillus thuringiensis strain JF19-2. Ann Microbiol. 60: 129134. https://doi.org/10.1007/s13213-009-0011-x 